\title{
The global scientific literature on applications and trends in the use of functional morphological groups in phytoplankton studies
}

\author{
Literatura científica global sobre aplicações e tendências no uso de grupos morfológicos \\ funcionais em estudos do fitoplâncton
}

\author{
Ricardina Maria Lemos Trindade ${ }^{1}$, Anny Kelly Nascimento Ribeiro ${ }^{1}$, João Carlos Nabout ${ }^{2 *}$ (D), \\ Jascieli Carla Bortolini ${ }^{1 *}$ (D)

\begin{abstract}
${ }^{1}$ Universidade Federal de Goiás - UFG, Campus Samambaia, Av. Esperança, s/n, Chácaras do Recreio Samambaia, CEP 74690-900, Goiânia, GO, Brasil

${ }^{2}$ Universidade Estadual de Goiás - UEG, Campus de Ciências Exatas e Tecnológicas Henrique Santillo, BR 153, 3105, CEP 75132-903, Anápolis, GO, Brasil

*e-mail: jcbortolini@ufg.br
\end{abstract}

Cite as: Trindade, R.M.L. et al. The global scientific literature on applications and trends in the use of functional morphological groups in phytoplankton studies. Acta Limnologica Brasiliensia, 2021, 33, e12.

\begin{abstract}
Aim: The application of deconstructive approaches in aquatic ecology has been increasing recently. Especially for phytoplankton, some functional classifications summarize similar traits of a group of species to understand organisms' response to landscape variability. One of these approaches deals with phytoplankton functional classification based on morphology (MBFG - Morphologically Based Functional Groups). Focusing on this approach, we systematic mapping the scientific literature to reveal this functional framework's applications for freshwater phytoplankton. Methods: For this study, we selected from the Thomson ISI Web of Science database all articles published between 2010 and 2018 dealing with MBFG. We recorded 179 manuscripts citing the phytoplankton functional classification based on morphology and, among them, we excluded three due to lack of access to information. Results: A clear temporal trend occurred with an increase in citations involving the morphological approach, with Brazil, Uruguay, and China as the countries with the highest number of studies. Of the total records, 60 manuscripts applied morphological classification in their studies, of which 23 manuscripts comprised comparative studies with other functional approaches. Most applications were for phytoplankton in lakes, with biomass being the most used metric for framing taxa in MBFG. The most often recorded groups are MBFG IV (medium-sized organisms without specialization), VII (large mucilaginous colonies), and III (large filamentous organisms with aerotopes). Conclusion: This study showed an increasing trend in the number of studies that used the functional approach based on MBFG. We believe that deconstructive approaches, such as MBFG, help assess issues of interest in phytoplankton ecology.
\end{abstract}

Keywords: planktonic algae; functional morphology; morphological traits; systematic literature mapping.

Resumo: Objetivo: A aplicaçáo de abordagens desconstrutivas em ecologia aquática tem aumentado recentemente. Em especial para o fitoplâncton, algumas classificaçôes funcionais vêm sendo utilizadas, como tentativa de sumarizar traços similares de um grupo de espécies para melhor compreender as respostas dos organismos à variabilidade da paisagem. Uma destas abordagens é a classificaçâo funcional do fitoplâncton baseada na morfologia (MBFG - Morphologically Based Functional Groups). Focando 
nesta abordagem, nós mapeamos sistematicamente a literatura científica para revelar as aplicaçóes e tendências deste enquadramento funcional para o fitoplâncton de ecossistemas aquáticos continentais. Métodos: Para tanto, nós selecionamos a partir da base de dados Thomson ISI Web Of Science todos os artigos publicados entre 2010 e 2018 que tratam de MBFG. Um total de 179 manuscritos que citaram a classificação funcional do fitoplâncton baseada na morfologia foram registrados, dos quais três foram excluídos por falta de acesso às informaçôes. Resultados: Foi observada uma clara tendência temporal no aumento no número de citações envolvendo a abordagem morfológica, sendo Brasil, Uruguai e China os países com os maiores números de estudos. Do total de registros, 60 manuscritos aplicaram a classificação morfológica em seus estudos e 23 destes compreendem estudos comparativos com outras abordagens funcionais. Nós detectamos que a maior parte das aplicaçóes foram realizadas para o fitoplâncton de lagos, sendo biomassa a métrica mais utilizada para o enquadramento dos táxons em MBFG. MBFG IV (organismos de tamanho médio sem especialização), VII (grandes colônias mucilaginosas) e III (grandes organismos filamentosos com aerótopos) foram os grupos mais frequentemente registrados. Conclusóes: Este estudo mostrou tendência crescente no número de estudos que utilizaram a abordagem funcional baseada na morfologia (MBFG). Acreditamos que abordagens desconstrutivas, como MBFG, são uma ferramenta útil para avaliar questóes de interesse na ecologia do fitoplâncton.

Palavras-chave: algas planctônicas; morfologia funcional; traços morfológicos; mapeamento sistemático da literatura.

\section{Introduction}

The application of deconstructive approaches in aquatic ecology has been increasing recently, especially for phytoplankton, where functional classifications have been used, as an attempt to summarize similar traits of a group of species for a better understanding of the organisms' response to landscape variability (Salmaso et al., 2015). Phytoplankton components have different traits of morphology, physiology, behavior, and life history, directly related to reproduction, resource acquisition, and predation prevention. These organisms address fundamental ecological issues, primarily due to their small, short size generation time and large populations (Litchman \& Klausmeier, 2008).

The phytoplankton community's diversity directly reflects environmental variability and the use of resources, enabling species to be classified according to their functional properties (Reynolds et al., 2002) to predict or explain the community structure about different ecological axes (Brasil \& Huszar, 2011). Differences in morphology, for example, reflect the functional properties of phytoplankton that will be selected under particular environmental conditions (Kruk $\&$ Segura, 2012). Thus, traits such as cell size, cell shape, and ability to form colonies, for example, are highly dependent on light levels, nutrient concentrations, and predation pressure (NaselliFlores et al., 2007; Litchman \& Klausmeier, 2008; Litchman et al., 2015; Ryabov et al., 2021). In this sense, functional groups can facilitate methodology in devising generalizations about a group of species and determining their distributions (Litchman et al., 2012).

Several authors have proposed and used approaches to group phytoplankton species, considering functional similarities and the relationship between organisms and the environment. The first proposal based on functional characteristics of phytoplankton was based on the $r$ and $K$ selection interpreted by Margalef (1978), which was later modified by Reynolds (1988) for CSR grouping, which accommodated competitive, stress-tolerant, and ruderal strategists (for a review, see Kruk et al., 2020). After that, other classifications emerged, relating different traits, such as size distribution (Platt \& Denman, 1978; Kamenir et al., 2004, 2006), shape (Stanca et al., 2013), ecological and phenological attributes (Reynolds et al., 2002; Padisák et al., 2009), structural, functional and taxonomic attributes (Salmaso \& Padisák, 2007).

In addition to these functional approaches applied to phytoplankton, another functional classification is based on morphology (MBFG - Morphologically Based Functional Groups) proposed by Kruk et al. (2010). The base of this classification is the morphometric structure of phytoplanktonic organisms, according to nine descriptors: volume, surface, surface-volume ratio, maximum linear dimension, presence of mucilage, flagella, aerotopes, and heterocytes. From such descriptors, Kruk et al. (2010) organized seven functional groups: Group I - small- size organisms with a high surface-to-volume ratio; Group II - small flagellated organisms with a siliceous exoskeletal, Group III - large filamentous 
organisms with the presence of aerotopes; Group IV - organisms of medium size lacking specialized traits; Group V - unicellular flagellates of medium to large size; Group VI - non-flagellated organisms with the presence of silica exoskeleton; Group VII - large mucilaginous colonies.

Among the different functional classifications used for phytoplankton, the MBFG approach has been applied in other studies and aquatic ecosystems in different regions of the world (Fraisse et al., 2013; Segura et al., 2013; Bortolini et al., 2014; Bortolini \& Bueno, 2017; Chen et al., 2015; Huszar et al., 2015; Mihaljević et al., 2013, 2015; Amorim et al., 2019; Magalhães et al., 2020). Besides, some studies have made comparisons by testing the efficiency of the morphological approach with other types of groupings (Izaguirre et al., 2012; Hu et al., 2013; Petar et al., 2014; Machado et al., 2015; Machado et al., 2016; Rangel et al., 2016; Lobo et al., 2018; Santana et al., 2018; Bortolini et al., 2019; Cupertino et al., 2019). Thus, it is recognized that classification based on morphology has been a relevant tool applied to freshwater phytoplankton ecological studies.

From the use of the functional approach based on morphological traits by Kruk et al. (2010), is that we systematic mapping of the scientific literature, revealing the applications and trends of this functional classification of the freshwater phytoplankton. Our goal is to answer the following questions: i) What is the total number of articles that cited the MBFG approach, highlighting how many articles used this approach? ii) What is the temporal trend in the number of articles that used the MBFG approach? iii) How often the functional approach is used in different countries? iv) What are the main keywords found in the articles and their co-occurrence structure? v) What is the frequency of using MBFG in different types of metrics (e.g., biomass, density, among others) and types of aquatic ecosystems? vi) Was a comparison made with another functional classification, and what methodology of comparison between metrics? vii) Which are the most found MBFG categories in the scientific literature? viii) Is there a correspondence between any MBFG and aquatic ecosystems?

\section{Materials and Methods}

We selected all articles in the Thomson ISI Web of Science database published between 2010 and 2018 that cited the paper "A morphological classification capturing functional variation in phytoplankton” by Kruk et al. (2010, p.614).
Because it was published in 2010, we listed the articles starting that year.

For each article, we extracted the following information: (a) the year of publication, (b) the country of study of the research, (c) which are the most used keywords to summarize the research, (d) if the article only cited Kruk et al. (2010) or if the MBFG classification was applied, (e) the type of metric used to fit the MBFG, (f) the type of environment being studied, ( $g$ ) if the MBFG classification was compared to another functional classification and which methodology of comparison was applied, (h) which MBFG was more frequent in the results of the articles (number of manuscripts that have a certain MBFG).

The temporal trend of publications that cited and used the MBFG was measured by associating the articles with publication year. Besides, we compared the total number of publications on freshwater phytoplankton during the same period to compare the two temporal trends (for the latter, we search for the keywords "Phytoplankton" AND "Freshwater"). For that, we performed a linear regression analysis. We also assessed the co-occurrence of keywords most used in publications, using the Bibliometrix package (Aria \& Cuccurullo, 2017). In this analysis, the keywords are the units (vertex in the co-occurrence network), and the connections (links) indicate the combined occurrence between the words. The font size of the words indicates the frequency with which the keyword occurred in the analyzed articles. The colors indicate which words belong to the same group (color) based on similarity (i.e., co-occurrence). Groups are formed based on the $k$-means method (see details in Aria \& Cuccurullo, 2017).

To assess the association of MBFGs with types of environments, we performed a detrended correspondence analysis (DCA), using a matrix with MBFGs and the number of times that each group occurred in different types of environments. The dependency relationship between the two factors (i.e., MBFG and types of the environment) was assessed using the chi-square test. All analyzes were performed using the software $\mathrm{R}$ (R Development Core Team, 2018).

\section{Results}

The total number of publications cited by Kruk et al. (2010) between 2010 and 2018 was 179. Of the total number of manuscripts collected, three were excluded from the analysis due to lack of access. We observed a clear temporal trend (Figure 1a, b) 
in the increase in the number of citations involving the MBFG approach $\left(\mathrm{R}^{2}=0.94 ; p<0.01\right)$, following the same temporal trend of total production on freshwater phytoplankton $\left(\mathrm{R}^{2}=0.95 ; p<0.01\right)$ in the same period. We also observed the temporal trend (Figure 1c) in the increase in the number of studies that applied the MBFG classification $\left(\mathrm{R}^{2}=0.87 ; p<0.01\right)$. The countries with the largest number of studies were Brazil, Uruguay, and China (Figure 2).

The 30 most used keywords in publications are presented in Figure 3. The term "phytoplankton" had the highest frequency of occurrence, followed by "functional groups" and "traits". The high occurrence and strong correlation between these terms is expected, given the scope and objective of
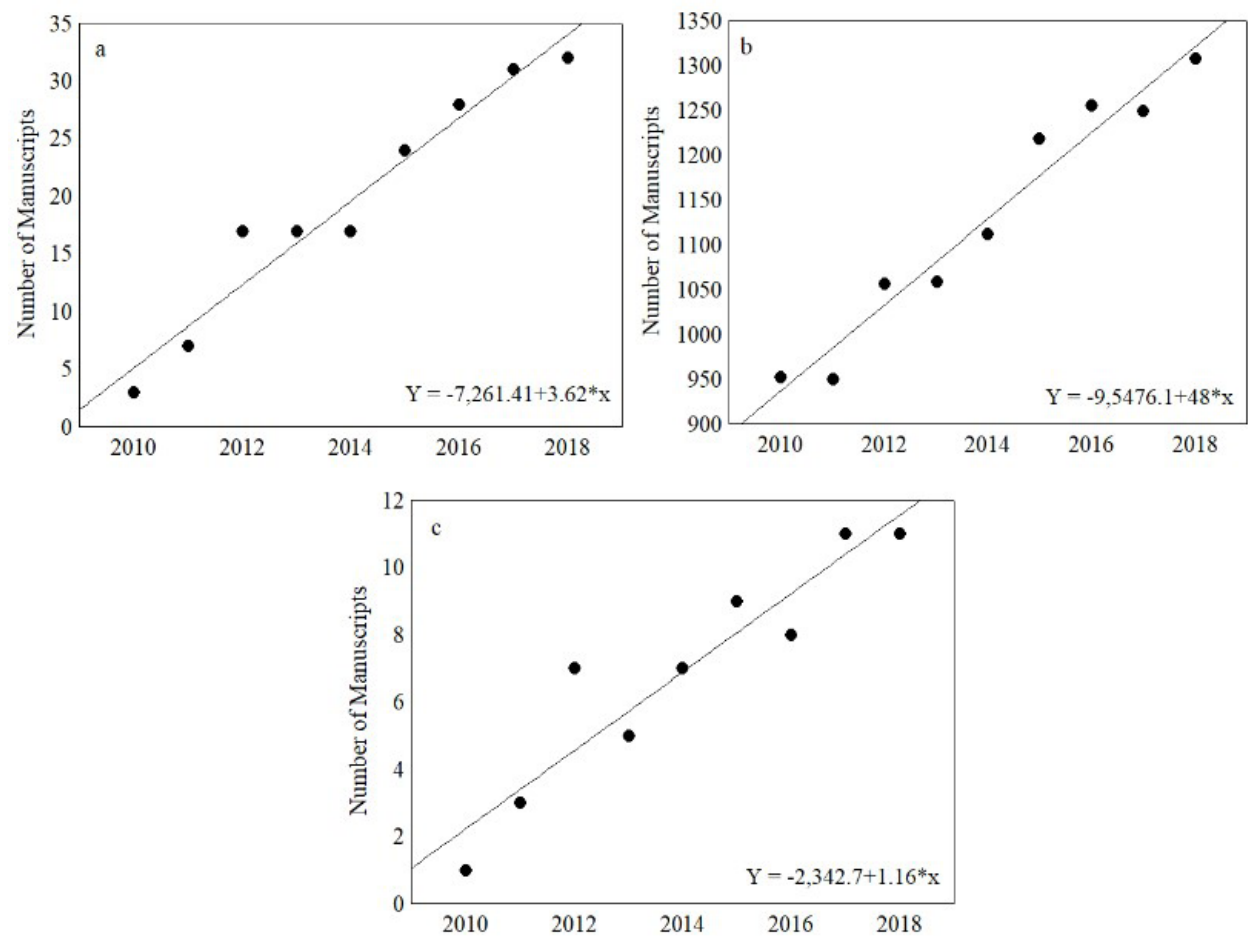

Figure 1. Temporal trends in the number of manuscripts referencing (a) Kruk et al. (2010), (b) the total world production on freshwater phytoplankton between 2010 and 2018, and (c) studies that applied the MBFG classification. ${ }^{*}$ Multiplication sign.

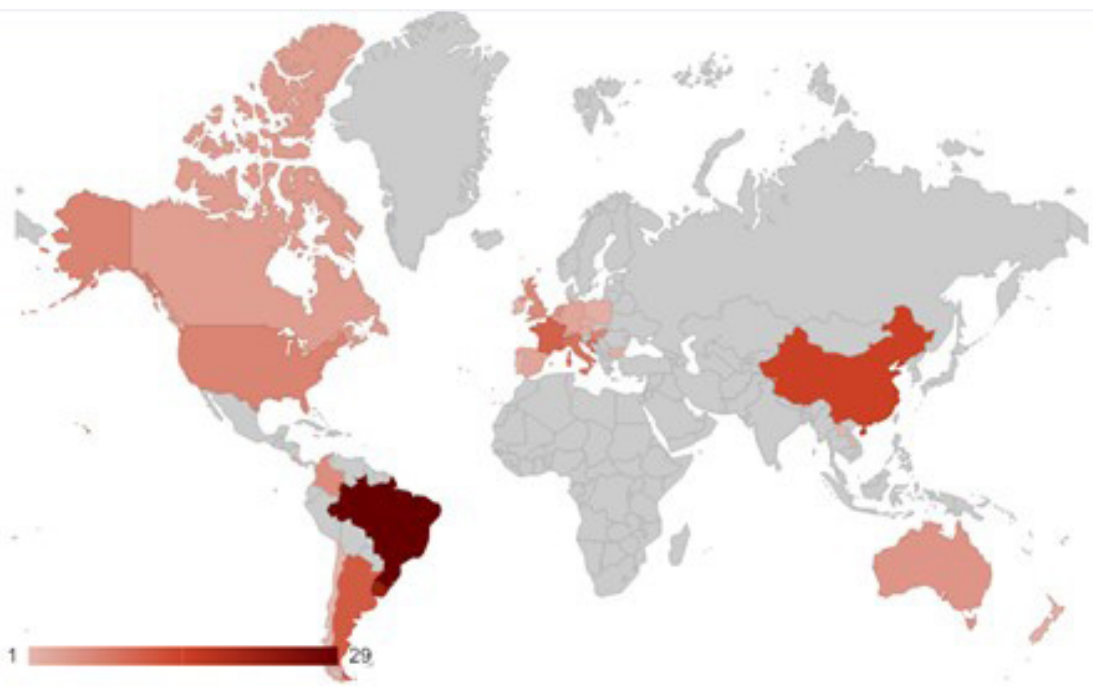

Figure 2. The distribution of the countries in the global scientific production between 2010 and 2018, referring to Kruk et al. (2010). 


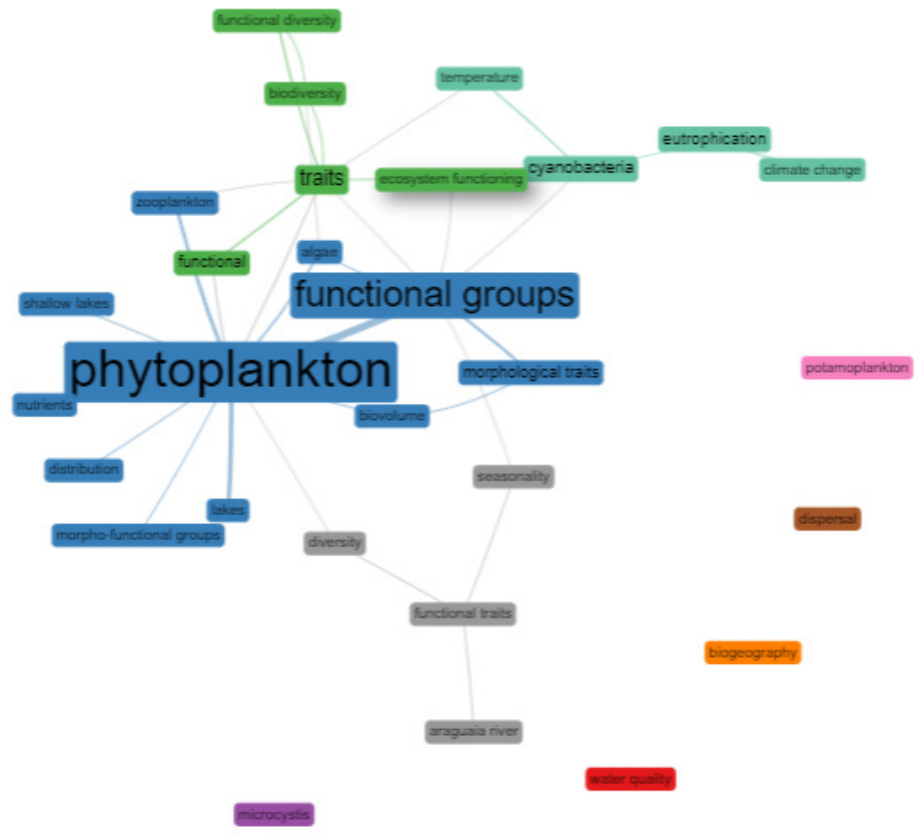

Figure 3. Network co-occurrence of the 30 more used keywords in papers published between 2010 and 2018, referring to Kruk et al. (2010). The size of the nodes represents the proportion of the frequency of occurrence. The lines represent the connection relationship between two keywords, and the thickness of the lines represents the strength of the correlation.

MBFG. Although some words occur in isolation, there are at least three main groups of keywords that co-occur. The first group (blue), formed by the terms with the most frequent occurrence (e.g. phytoplankton, functional groups), was associated with words such as "nutrients", "floodplain", and "shallow lakes". The second group (light green) encompassed words such as "cyanobacteria", "eutrophication", and "climate change". This finding demonstrates the use of MBFG in research on the water quality of the environment. The third group (green) grouped words such as "biodiversity", "ecosystem functioning", and "traits", indicating its use for recognizing biodiversity and functioning of aquatic ecosystems.

Of the total number of analyzed manuscripts, 60 publications applied the MBFG classification, and the other publications cited only the reference by Kruk et al. (2010) in their theoretical backgrounds. Considering the phytoplankton frameworks on MBFG in these studies, our results showed biomass as the primary metric to classify taxa in MBFG, followed by density and richness. Only two manuscripts used the organism size and maximum growth rate as a framework (Figure 4a).

Regarding the types of aquatic ecosystems in which studies using the MBFG were developed, the results indicated that this classification was applied mainly to lake ecosystems, followed by rivers and reservoirs (Figure $4 \mathrm{~b}$ ). Of the total number of publications, 23 made comparisons with other types of functional classifications, using canonical correspondence analysis (CCA), redundancy analysis (RDA), Mantel, and Procrustes tests as methods of analysis (Figure 4c). The primary comparisons were between Reynolds Functional Groups (RFG - Reynolds et al., 2002; Padisák et al., 2009) and morphofunctional groups (MFG - Salmaso \& Padisák, 2007). Regarding the representativeness of the MBFG in the manuscripts, our data showed the MBFG IV, VII, and III as the most recorded groups, followed by VI, I, V, and II (Figure 4d).

According to the DCA, there was no correlation between types of environments and MBFG (chisquare $=25,228, p=0.9104$, Figure 5).

\section{Discussion}

Studies on phytoplankton communities increased significantly in the global scientific literature (Carneiro et al., 2008; Wang et al., 2015), and therefore the systematic mapping of literature is relevant to determine trends and biases in the development of research (e.g., Pullin \& Stewart, 2006; Nabout et al., 2015), as well as direct future 

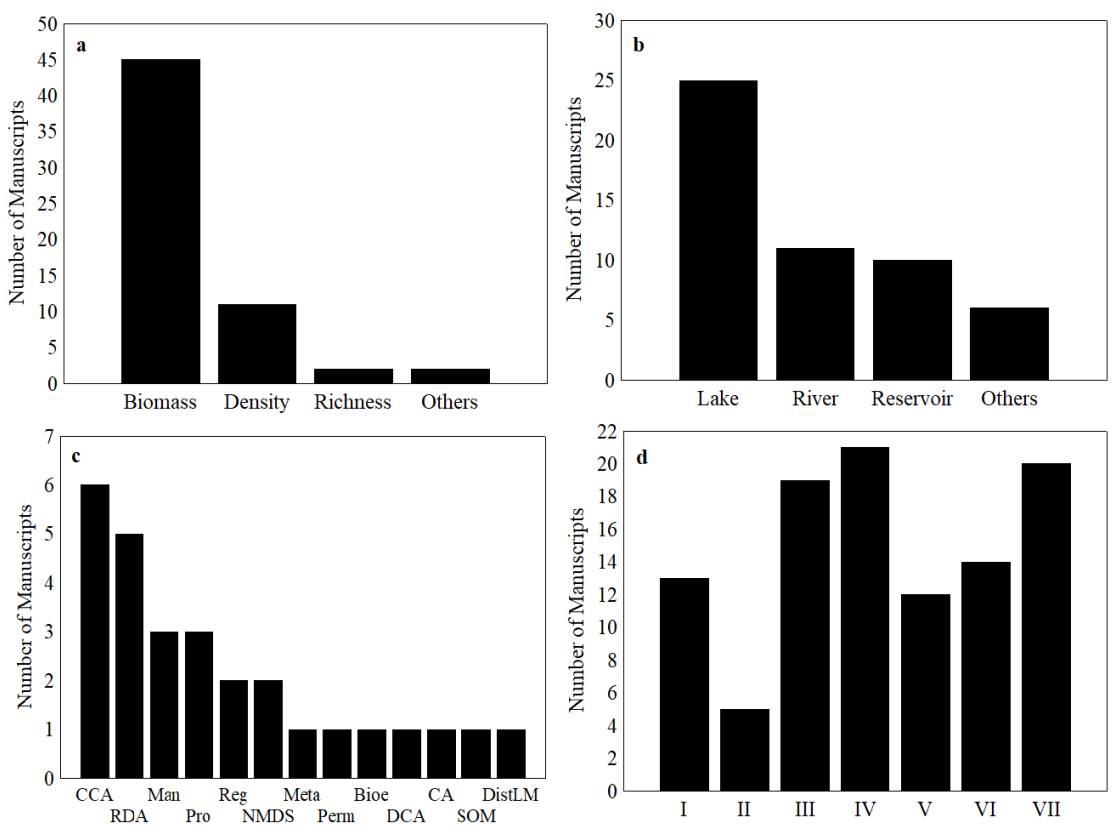

Figure 4. (a) Types of metrics used in the manuscripts to frame the phytoplankton taxa in MBFG; (b) Types of aquatic ecosystems in which the MBFG was applied; (c) Analysis methods used for comparisons between MBFG and other functional approaches (CCA - Canonical Correspondence Analysis; RDA - Redundancy Analysis; Man - Mantel Test; Pro - Procrust Test; Reg - Regression Analysis; NMDS - Non-Metric Multidimensional Scaling Analysis; Meta - Meta-Analysis; Perm - Permutational Analysis of Variance; Bioe - Bioenv Test; DCA - Detrended Correspondence Analysis, CA - Correspondence Analysis, SOM - Self- organizing Map, DistLM - Distance-based Linear Models); (d) Representation of MBFG in the results of the manuscripts that applied the MBFG.

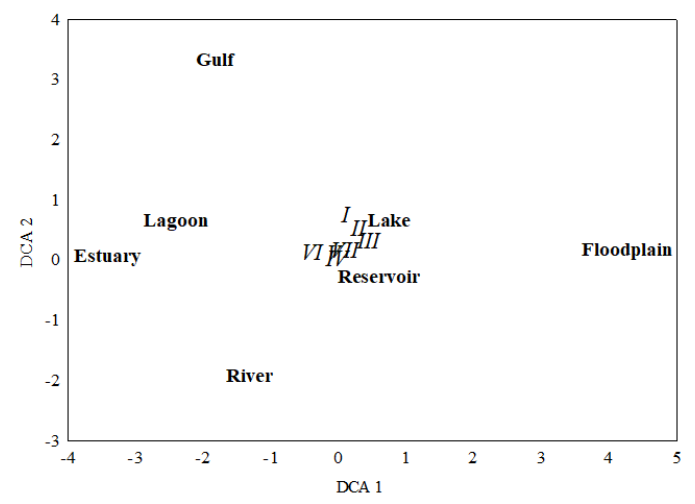

Figure 5. Detrended Correspondence Analysis for the association between MBFG and types of environments recorded in the global scientific literature between 2010 and 2018 .

studies. Here, we found an increase in the number of ecological surveys using the MBFG approach over the years, following the same temporal trend of total scientific production on phytoplankton in freshwater. This trend indicates the scientific community's interest since the use of MBFG may be associated with the attempt of synthesis and facilitation of explanations and discussions of the relationship between phytoplankton and environmental variability in aquatic ecosystems (Brasil \& Huszar, 2011). However, functional groups are not intended to replace information collected from species (Bortolini et al., 2016), but they are a way to simplify the understanding of ecosystem processes.

It was also possible to detect how some researchers conduct comparative studies between the MBFG and other functional approaches traditionally applied to phytoplankton ecology in an attempt to seek the most efficient responses and greater predictive power (Izaguirre et al., 2012; Hu et al., 2013; Petar et al., 2014; Machado et al., 2015; Machado et al., 2016; Rangel et al., 2016; Lobo et al., 2018; Santana et al.,, 2018; Bortolini et al., 2019; Cupertino et al., 2019). Different functional metrics have been used in the literature on phytoplankton, highlighting the MBFG (investigated in this article) and others as, for example, RFG, MFG. The comparison between the metrics is an essential point since the metrics can be complementary or redundant. Such comparisons also use modern and robust data analysis methods, which make the studies more substantial. For example, in this study, we found that the ordination and comparison tests (CCA, 
RDA, Procrustes) and matrix correlation tests (Mantel) were the most used. Although the tests use different statistical strategies, both are efficient for comparing the groups.

When we analyze the keywords with the highest incidence in the raised manuscripts, we realize that there is a relationship between the themes of scientific studies and the use of the MBFG framework because there is a tendency to use words such as "phytoplankton" and "functional groups". Besides, at least three groups of keywords co-occur, evidencing trends in ecological studies of phytoplankton in the current scenario and the applying MBFG, especially about eutrophication issues, climate change, and ecosystem functioning. These trends reflect the importance of the effects of biodiversity and how it affects the ecosystem (Isbell et al., 2018), and this has called the attention (Wang et al., 2015). For example, warming and eutrophication are essential global change factors for natural ecosystems (Binzer et al., 2016).

In relation to the study countries, we evidenced that Brazil, Uruguay, and China lead the number of studies. Brazil, for example, has been considered responsible for much of the scientific production on phytoplankton in Latin America (Nabout et al., 2015). Also, countries such as Uruguay and China have excellent researchers in this area of knowledge, directly influencing the development of research in phytoplankton ecology and, consequently, in the application of MBFG (for example, Carla Kruk, the principal author of the original MBFG manuscript, is from Uruguay). As the 15th country in the world with the most extensive scientific production on phytoplankton (Carneiro et al., 2008), China is in the top 20 countries for publications on phytoplankton and cooperation correlations (Wang et al., 2015).

Our study also revealed biomass as the most frequent metric used for species classification into the MBFG. Biomass is of paramount importance in the phytoplankton communities' studies, highlighting a meaningful proxy to estimate the energy available at a certain trophic level. Besides, it is an essential proxy in the relationship between community structure changes and environmental variability (Philipart et al., 2000).

Lakes and reservoirs showed the largest number of studies that applied the MBFG framework to phytoplankton in this survey. This finding is probably linked to the importance of lakes and reservoirs as elements in the continental landscape and the significant role of these freshwater ecosystems in many key processes (Downing et al., 2006), raising scientists' interest in investigations. Reservoirs, for example, generate risks due to impacts but offer opportunities for integrating watershed management and water allocation for multiple uses (Tundisi, 2018), which also creates interest for science. Thus, understanding these ecosystems' dynamics and integrity may have influenced the highest number of studies recorded in these environments.

The MBFG approach suggests a way of framing the phytoplankton based on the morphological traits of the organisms. It has been used to explain and predict the phytoplankton responses to the environmental conditions, reflecting the organisms' habitat template (Kruk \& Segura, 2012). We found that MBFG IV had the greatest representativeness in the results of the studies. This group comprises organisms without specialized traits, such as chlorophyceans, xanthophyceans, desmids, and cyanobacteria without specialized cells. The success of this group is related: i) to good water quality; ii) to the transitional ecosystem stages; and iii) to the combination of some ecological functions as a low nutrient concentration, high zooplankton abundance, and little light attenuation (Kruk et al., 2010; Kruk \& Segura, 2012). These features are standard in lake ecosystems (Izaguirre et al., 2012) and even in reservoir areas (Rangel et al., 2016). Almost with the same importance, are the MBFG VII composed of large mucilaginous colonies of chlorophyceans and cyanobacteria, and the MBFG III formed by large filamentous organisms with aerotopes (cyanobacteria). Although MBFG IV is diverse and associated with state transitions, we suggest that the studies expand the samplings over time to capture the effects of eutrophication and climate change since these events have been highlighted in the key-words.

In summary, in this scientometric survey, we found 60 articles that used the MBFG, mainly from Uruguay, Brazil, and China. They were primarily based on biomass and developed in lake ecosystems, followed by rivers and reservoirs. The number of studies of MBFG shows an increasing temporal trend following the direction of the total scientific literature on freshwater phytoplankton. MBFG IV is the group with the greatest representativeness in the studies. The keywords indicate the use of MBFG in research on the environmental water quality and for recognizing the biodiversity and functioning of aquatic ecosystems. CCA and RDA are the main analysis methods used for comparisons between 
MBFG and other functional approaches. Finally, our data reveal that deconstructive approaches, as MBFG, are helpful tools for assessing interest issues in phytoplankton ecology.

\section{Acknowledgements}

RMLT is grateful to UFG (Universidade Federal de Goiás) for an undergraduate scholarship for science.

\section{References}

AMORIM, C.A., VALENÇA, C.R., DE MOURAFALCÃO, R.H. and DO NASCIMENTO MOURA, A. Seasonal variations of morphofunctional phytoplankton groups influence the top-down control of a cladoceran in a tropical hypereutrophic lake. Aquatic Ecology, 2019, 53(3), 453-464. http://dx.doi.org/10.1007/s10452-01909701-8.

ARIA, M. and CUCCURULLO, C. Bibliometrix: an R-tool for comprehensive science mapping analysis. Journal of Informetrics, 2017, 11(4), 959-975. http:// dx.doi.org/10.1016/j.joi.2017.08.007.

BINZER, A., GUILL, C., RALL, B.C. and BROSE, $U$. Interactive effects of warming, eutrophication and size structure: impacts on biodiversity and foodweb structure. Global Change Biology, 2016, 22(1), 220-227. http://dx.doi.org/10.1111/gcb.13086. PMid:26365694.

BORTOLINI, J.C. and BUENO, N.C. Temporal dynamics of phytoplankton using the morphologybased functional approach in a subtropical river. Brazilian Journal of Botany, 2017, 40(3), 741-748. http://dx.doi.org/10.1007/s40415-017-0385-0.

BORTOLINI, J.C., DA SILVA, P.R.L., BAUMGARTNER, G. and BUENO, N.C. Response to environmental, spatial, and temporal mechanisms of the phytoplankton metacommunity: comparing ecological approaches in subtropical reservoirs. Hydrobiologia, 2019, 830(1), 45-61. http://dx.doi.org/10.1007/s10750-018-3849-8.

BORTOLINI, J.C., RODRIGUES, L.C., JATI, S. and TRAIN, S. Phytoplankton functional and morphological groups as indicators of environmental variability in a lateral channel of the Upper Paraná a River floodplain. Acta Limnologica Brasiliensia, 2014, 26(1), 98-108. http://dx.doi.org/10.1590/ S2179-975X2014000100011.

BORTOLINI, J.C., MORESCO, G.A., PAULA, A.C.M., JATI, S. and RODRIGUES, L.C. Functional approach based on morphology as a model of phytoplankton variability in a subtropical floodplain lake: a long-term study. Hydrobiologia, 2016, 767, 151-163. http://dx.doi.org/10.1007/ s10750-015-2490-z.
BRASIL, J. and HUSZAR, V.L.M. O papel dos traços funcionais na ecologia do fitoplâncton continental. Oecologia Australis, 2011, 15(4), 799-834. http:// dx.doi.org/10.4257/oeco.2011.1504.04.

CARNEIRO, F.M., NABOUT, J.C. and BINI, L.M. Trends in the scientific literature on phytoplankton. Limnology, 2008, 9(2), 153-158. http://dx.doi. org/10.1007/s10201-008-0242-8.

CHEN, N., LIU, L., LI, Y., QIAO, D., LI, Y., ZHANG, Y. and LV, Y. Morphology-based classification of functional groups for potamoplankton. Journal of Limnology, 2015, 74(AoP), 559-571. http://dx.doi. org/10.4081/jlimnol.2015.1173.

CUPERTINO, A., GÜCKER, B., VON RÜCKERT, G. and FIGUEREDO, C.C. Phytoplankton assemblage composition as an environmental indicator in routine lentic monitoring: Taxonomic versus functional groups. Ecological Indicators, 2019, 101, 522-532. http://dx.doi.org/10.1016/j.ecolind.2019.01.054.

DOWNING, J.A., PRAIRIE, Y.T., COLE, J.J., DUARTE, C.M., TRANVIK, L.J., STRIEGL, R.G., MCDOWELL, W.H., KORTELAINEN, P., CARACO, N.F., MELACK, J.M. and MIDDELBURG, J.J. The global abundance and size distribution of lakes, ponds, and impoundments. Limnology and Oceanography, 2006, 51(5), 23882397. http://dx.doi.org/10.4319/lo.2006.51.5.2388.

FRAISSE, S., BORMANS, M. and LAGADEUC, Y. Morphofunctional traits reflect differences in phytoplankton community between rivers of contrasting flow regime. Aquatic Ecology, 2013, 47(3), 315-327. http://dx.doi.org/10.1007/s10452013-9446-z.

HU, R., HAN, B. and NASELLI-FLORES, L. Comparing biological classifications of freshwater phytoplankton: a case study from South China. Hydrobiologia, 2013, 701(1), 219-233. http://dx.doi. org/10.1007/s10750-012-1277-8.

HUSZAR, V.L.M., NABOUT, J.C., APPEL, M.O., SANTOS, J.B.O., ABE, D.S. and SILVA, L.H. Environmental and not spatial processes (directional and non-directional) shape the phytoplankton composition and functional groups in a large subtropical river basin. Journal of Plankton Research, 2015, 37, 1190-1200. http://dx.doi.org/10.1093/ plankt/fbv084.

ISBELL, F., COWLES, J., DEE, L.E., LOREAU, D., REICH, P.B., GONZALEZ, A., HECTOR, A. and SCHMID, B. Quantifying effects of biodiversity on ecosystem functioning across times and places. Ecology Letters, 2018, 21(6), 763-778. http://dx.doi. org/10.1111/ele.12928. PMid:29493062.

IZAGUIRRE, I., ALLENDE, L., ESCARAY, R., BUSTINGORRY, J., PEREZ, G. and TELL, G. Comparison of morpho-functional phytoplankton classifications in human-impacted shallow lakes with different stable states. Hydrobiologia, 2012, 698(1), 
203-216. http://dx.doi.org/10.1007/s10750-0121069-1.

KAMENIR, Y., DUBINSKY, Z. and ZOHARY, T. Phytoplankton size structure stability in a mesoeutrophic subtropical lake. Hydrobiologia, 2004, 520(1-3), 89-104. http://dx.doi.org/10.1023/ B:HYDR.0000027729.53348.c7.

KAMENIR, Y., DUBINSKY, Z. and ZOHARY, T. The long-term patterns of phytoplankton taxonomic size-structure and their sensitivity to perturbation: a Lake Kinneret case study. Aquatic Sciences, 2006, 68(4), 490-501. http://dx.doi.org/10.1007/s00027006-0864-z.

KRUK, C. and SEGURA, A.M. The habitat template of phytoplankton morphology-based functional groups. Hydrobiologia, 2012, 698(1), 191-202. http://dx.doi. org/10.1007/s10750-012-1072-6.

KRUK, C., DEVERCELLI, M. and HUSZAR, V.L. Reynolds Functional Groups: a trait-based pathway from patterns to predictions. Hydrobiologia, 2020, 848(1), 113-129. http://dx.doi.org/10.1007/s10750020-04340-9.

KRUK, C., HUSZAR, V.L.M., PEETERS, E.T.H.M., BONILlA, S., COSTA, L., LÜRLING, M., REYNOLDS, C. and SCHEFFER, M. A morphological classification capturing functional variation in phytoplankton. Freshwater Biology, 2010, 55(3), 614-627. http://dx.doi.org/10.1111/j.13652427.2009.02298.x.

LITCHMAN, E. and KLAUSMEIER, C.A. Trait-based community ecology of phytoplankton. Annual Review of Ecology Evolution and Systematics, 2008, 39(1), 615-639. http://dx.doi.org/10.1146/annurev. ecolsys.39.110707.173549.

LITCHMAN, E., DE TEZANOS PINTO, P., EDWARDS, K.F., KLAUSMEIER, C.A., KREMER, C.T. and THOMAS, M.K. Global biogeochemical impacts of phytoplankton: a trait-based perspective. Journal of Ecology, 2015, 103(6), 1384-1396. http:// dx.doi.org/10.1111/1365-2745.12438.

LITCHMAN, E., EDWARDS, K.F., KLAUSMEIER, C.A. and THOMAS, M.K. Phytoplankton niches, traits and eco-evolutionary responses to global environmental change. Marine Ecology Progress Series, 2012, 470, 235-248. http://dx.doi.org/10.3354/ meps09912.

LOBO, M.T.M.P.S., DE SOUZA NOGUEIRA, I., FABRIS SGARBI, L., NUNES KRAUS, C., DE OLIVEIRA BOMFIM, E., GARNIER, J., DA MOTTA MARQUES, D. and BONNET, M.-P. Morphology-based functional groups as the best tool to characterize shallow lake-dwelling phytoplankton on an Amazonian floodplain. Ecological Indicators, 2018, 95, 579-588. http://dx.doi.org/10.1016/j. ecolind.2018.07.038.
MACHADO, K.B., BORGES, P.P., CARNEIRO, F.M., DE SANTANA, J.F., VIEIRA, L.C.G., DE MORAES HUSZAR, V.L. and NABOUT, J.C. Using lower taxonomic resolution and ecological approaches as a surrogate for plankton species. Hydrobiologia, 2015, 743(1), 255-267. http://dx.doi. org/10.1007/s10750-014-2042-y.

MACHADO, K.B., TERESA, F.B., VIEIRA, L.C.G., HUSZAR, V.L.M. and NABOUT, J.C. Comparing the effects of landscape and local environmental variables on taxonomic and functional composition of phytoplankton communities. Journal of Plankton Research, 2016, 38(5), 1334-1346. http://dx.doi. org/10.1093/plankt/fbw062.

MAGALHÃES, L., RANGEL, L.M., ROCHA, A.M., CARDOSO, S.J. and SILVA, L.H.S. Responses of morphology-based phytoplankton functional groups to spatial variation in two tropical reservoirs with long water-residence time. Inland Waters, 2020, 11(1), 29-43. http://dx.doi.org/10.1080/2044204 1.2020.1745007.

MARGALEF, R. Life-forms of phytoplankton as survival alternatives in an unstable environment. Oceanologica Acta, 1978, 1, 493-509.

MIHALJEVIĆ, M., ŠPOLJARIĆ, D., STEVIĆ, F., ŽUNA, T. and PFEIFFER, T. Assessment of flood-induced changes of phytoplankton along a river-floodplain system using the morphofunctional approach. Environmental Monitoring and Assessment, 2013, 185(10), 8601-8619. http://dx.doi. org/10.1007/s10661-013-3198-z. PMid:23604727.

MIHALJEVIĆ, M., ŠPOLJARIĆ, D., STEVIĆ, F. and ŽUNA PFEIFFER, T. Spatial pattern of phytoplankton based on the morphology-based functional approach along a river-floodplain gradient. River Research and Applications, 2015, 31(2), 228-238. http://dx.doi.org/10.1002/rra.2739.

NABOUT, J.C., CARNEIRO, F.M., BORGES, P.P., MACHADO, K.B. and HUSZAR, V.L.M. Brazilian scientific production on phytoplankton studies: national determinants and international comparisons. Brazilian Journal of Biology $=$ Revista Brasileira de Biologia, 2015, 75(1), 216-223. http://dx.doi.org/10.1590/1519-6984.11713. PMid:25945640.

NASELLI-FLORES, L., PADISÁK, J. and ALBAY, M. Shape and size in phytoplankton ecology: do they matter? Hydrobiologia, 2007, 578(1), 157-161. http://dx.doi.org/10.1007/s10750-006-2815-z.

PADISÁK, J., CROSSETTI, L.O. and NASELLIFLORES, L. Use and misuse in the application of the phytoplankton functional classification: a critical review with updates. Hydrobiologia, 2009, 621(1), 1-19. http://dx.doi.org/10.1007/s10750008-9645-0.

PETAR, Ž., MARIJA, G.U., KORALJKA, K.B., ANĐELKA, P.-M. and JUDIT, P. Morpho-functional 
classifications of phytoplankton assemblages of two deep karstic lakes. Hydrobiologia, 2014, 740(1), 147 166. http://dx.doi.org/10.1007/s10750-014-1950-1.

PHILIPPART, C.J.M., CADÉE, G.C., VAN RAAPHORST, W. and RIEGMAN, R. Long-term phytoplankton-nutrient interactions in a shallow coastal sea: Algalcommunity structure, nutrient budgets, and denitrification potential. Limnology and Oceanography, 2000, 45(1), 131-144.

PLATT, T. and DENMAN, K. The structure of pelagic ecosystem. Rapports et Proces-Verbaux des Reunions, 1978, 173, 60-65.

PULLIN, A.S. and STEWART, G.B. Guidelines for systematic review in conservation and environmental management. Conservation Biology, 2006, 20(6), 1647-1656. http://dx.doi.org/10.1111/j.15231739.2006.00485.x. PMid:17181800.

R DEVELOPMENT CORE TEAM. $R$ : A language and environment for statistical computing [online]. Vienna: R Foundation for Statistical Computing, 2018 [viewed 18 July 2021]. Available from: http://www.R-project.org/

RANGEL, L.M., SOARES, M.C.S., PAIVA, R. and SILVA, L.H.S. Morphology-based functional groups as effective indicators of phytoplankton dynamics in a tropical cyanobacteria-dominated transitional river-reservoir system. Ecological Indicators, 2016, 64, 217-227. http://dx.doi. org/10.1016/j.ecolind.2015.12.041.

REYNOLDS, C.S. Functional morphology and the adaptive strategies of freshwater phytoplankton. In: Sandgren, C.D., ed. Growth and reproductive strategies of freshwater phytoplankton. Cambridge: Cambridge University Press, 1988, pp. 388-433.

REYNOLDS, C.S., HUSZAR, V., KRUK, C., NASELLIFLORES, L. and MELO, S. Towards a functional classification of the freshwater phytoplankton. Journal of Plankton Research, 2002, 24(5), 417-428. http:// dx.doi.org/10.1093/plankt/24.5.417.

RYABOV, A., KERIMOGLU, O., LITCHMAN, E., OLENINA, I., ROSELli, L., BASSET, A., STANCA, E. and BLASIUS, B.. Shape matters: the relationship between cell geometry and diversity in phytoplankton. Ecology Letters, 2021, 24(4),
847-861. http://dx.doi.org/10.1111/ele.13680. PMid:33471443.

SALMASO, N. and PADISÁK, J. Morpho-Functional Groups and phytoplankton development in two deep lakes (Lake Garda, Italy and Lake Stechlin, Germany). Hydrobiologia, 2007, 578(1), 97-112. http://dx.doi.org/10.1007/s10750-006-0437-0.

SALMASO, N., NASELLI-FLORES, L. and PADISÁK, J. Functional classifications and their application in phytoplankton ecology. Freshwater Biology, 2015, 60(4), 603-619. http://dx.doi.org/10.1111/ fwb. 12520 .

SANTANA, L.M., NABOUT, J.C. and FERRAGUT, C. Taxonomic and functional classifications of phytoplankton in tropical reservoirs with different trophic states. Brazilian Journal of Botany, 2018, 41(1), 91-102. http://dx.doi.org/10.1007/s40415017-0428-6.

SEGURA, A.M., KRUK, C., CALLIARI, D. and FORT, $\mathrm{H}$. Use of a morphology-based functional approach to model phytoplankton community succession in a shallow subtropical lake. Freshwater Biology, 2013, 58(3), 504-512. http://dx.doi.org/10.1111/j.13652427.2012.02867.x.

STANCA, E., CELLAMARE, M. and BASSET, A. Geometric shape as a trait to study phytoplankton distributions in aquatic ecosystems. Hydrobiologia, 2013, 701(1), 99-116. http://dx.doi.org/10.1007/ s10750-012-1262-2.

TUNDISI, J.G. Reservoirs: new challenges for ecosystem studies and environmental Management. Water Security, 2018, 4-5, 1-7. http://dx.doi.org/10.1016/j. wasec.2018.09.001.

WANG, C., LIU, Y., LI, X., LAI, Z., TACKX, M. and LEK, S. A bibliometric analysis of scientific trends in phytoplankton research. International Journal of Limnology, 2015, 51(3), 249-259. http://dx.doi. org/10.1051/limn/2015019.

Received: 14 July 2020

Accepted: 12 May 2021

Associate Editors: André Andrian Padial. 